УДК 656.2.078

\title{
РЕСТРУКТУРИЗАЦІЯ ЗАЛІЗНИЧНОГО ТРАНСПОРТУ УКРАЇНИ НА ОСНОВІ РЕГІОНАЛЬНО-ГАЛУЗЕВОЇ МОДЕЛІ УПРАВЛІННЯ
}

\author{
Ейтутіс Г.Д., о.е.н., професор, \\ Божнк А.Р., к.е.н., доцент (ДУІТ)
}

Обгрунтовані теоретичні $i$ практичні аспекти реструктуризації залізниць Украӥни на основі регіонально-галузевої моделі управління. За допомогою дерева цілей функиіонально-об'єктної системи реформування залізниць Украӥни сформовані принциии $і$ стратегї управління залізницями. Надані авторські пропозиції щуодо визначення адміністративно-територіального устрою регіональних підприємств, а саме в місиях і межах дислокації регіональних центрів управління перевезеннями.

Ключеві слова: трансформаційні процеси, реформування, реструктуризація, реорганізація, регіональний центр управління перевезеннями, економічні райони, регіональні підприємства.

\section{РЕСТРУКТУРИЗАЦИЯ ЖЕЛЕЗНОДОРОЖНОГО ТРАНСПОРТА УКРАИНЫ НА ОСНОВЕ РЕГИОНАЛЬНОЙ ОТРАСЛЕВОЙ МОДЕЛИ УПРАВЛЕНИЯ}

Ейтутис Г.Д., о.е.н., професор, Божск А.Р., к.е.н., доцент (ДУИТ)

Обоснованы теоретические и практические аспекты реструктуризачии железных дорог Украины на основе регионально-отраслевой модели управления. С помощьюю дерева целей функционально-объектной системы сформированы принципь и стратегии управления железными дорогами. Представлены авторские предложения относительно определения административно-территориального устройства региональных предприятий, а именно в местах и пределах дислокации региональньх центров управления перевозками.

Ключевые слова: трансформационные процессы, реформирование, реструктуризация, реорганизация, региональный центр управления перевозками, региональные предприятия.

\section{RESTRUCTURING OF RAILWAY TRANSPORT BASED ON REGIONAL SECTORAL MANAGEMENT MODEL}

\author{
Eitutis G.D., doctor of Economics, Professor, \\ Bozhok A.R., PhD of Economics, associate Professor (SUIT)
}

Theoretical and practical aspects of the restructuring of the railways of Ukraine based on the regional-industrial model of management are substantiated. Such principles as specialization, centralization, efficiency, horizontal interaction, regional compactness and others are defined. Using the goals tree of the functional-object system, the principles and strategies of railway management are formed. As a result, the organizational structure of the country's railways based on a functional-objective management system is presented.

(C) Ейтутіс Г.Д.,

Божок А.P.

Вісник економіки транспорту і промисловості № 68, 2019 
It is also noted that the formation of the administrative-territorial structure of a regional enterprise is advisable to be carried out at the places and borders of regional transportation control centers deployment.

In the process of creating regional transportation control centers, it is proposed: a gradual withdrawal from the railway divisions that belong to the competitive sector of the industry; the creation of passenger transportation operator companies, including their entry into the market with their own fleet of locomotives. It is proposed to include regional infrastructure service enterprises and regional transportation control centers in the structure of regional enterprises, which would be subordinated vertically to the Ukrainian railway operation subject".

It is indicated that the regional transportation control centers should manage the technological process of organizing the movement of trains through the dispatching apparatus by all railway stations. Authors' proposals are presented regarding the definition of the administrative-territorial structure of regional enterprises, namely: in the places and within the location of regional transportation control centers. The positive economic and legal results from the implementation of the regional-sectoral management model are determined.

Keywords: transformation processes, reformation, restructuring, reorganization, regional transportation management center, economic regions, regional enterprises

\begin{abstract}
Постановка проблеми та ії зв'язок 3 науковими чи практичними завданнями. Трансформаційні процеси, що відбуваються в сучасних умовах на залізничному транспорті світу 3 одного боку включають значну частину проблем загального характеру (розмежування державних i господарських функцій управління, відокремлення експлуатаційної діяльності від інфраструктури, ліквідація перехресного субсидування пасажирських перевезень за рахунок вантажних, залучення інвестицій та інші проблеми), а 3 іншого - специфічні особливості кожної залізниці, які пов'язані 3 вибором ефективної моделі господарського механізму.
\end{abstract}

Структурні перетворення, які регламентуються Державною цільовою програмою реформування залізничного транспорту на 2010-2019 роки, трактують як послідовну реорганізацію територіально-функціональної структури управління єдиного суб'єкта господарювання у вертикальноінтегровану.

Однак, досвід сусідніх залізничних держав (Польщі, Румунії, Словаччини) показав, що ігнорування територіальнофункціональної системи управління i перехід до лише вертикальної моделі управління призводить до погіршення управління галуззю.

I навпаки, послідовне вдосконалення територіально-функціональної структури управління на базі інтеграції функціонально-об'єктної системи i вертикальної моделі створює умови для ефективного управління залізничним транспортом (досвід залізниць Німеччини).

Це особливо важливо 3 огляду на політичні події в Україні, кінцевим результатом яких стане стабілізація даної галузі в Україні 3 подальшим реформуванням національної економіки, в тому числі залізниць на основі регіоналізації транспортного обслуговування.

Аналіз останніх досліджень i публікацій. Питаннями районування, а також діяльності залізничного транспорту України в розрізі адміністративного устрою в колишньому Радянському Союзі i вже в роки незалежності України відповідної уваги не приділялося ні науково-дослідними інститутами, ні суб' Єктами залізничного транспорту 3 причин діючого до нині жорсткого централізованого механізму управління залізничним транспортом, межі залізниць

Вісник економіки транспорту і промисловості № 68, 2019 
яких були встановлені ще у радянські роки. Ліквідація відділків залізниць у 2002 року ще більш дистанціювала регіони i залізничний транспорт від співробітництва щодо вирішення спільних питань. Проблемам реформування залізничного транспорту приділені праці Гненного М.В., Диканя В.Л., Дейнеки О.Г., Кривопішина B.M., Панченко O.I. та ін. [37]

Виділення невирішених частин загальної проблеми. Актуальність обгрунтованого розв'язання цієї проблеми зростає насамперед у зв'язку 3 необхідністю перегляду старих ланок управління залізничної галузі 3 причин змін районів тяжіння транспортних вантажопотоків, нормативно-правової бази, a також удосконалення господарського механізму після створення незалежної української держави.

На жаль, у концепції державної регіональної політики, яка затверджена Наказом Президента України від 25 травня 2001 року №341/2001 немає не тільки розділу щодо взаємодії регіонів i транспортників, але i власне слова «транспорт».

Слід зазначити, що питання адміністративно-територіального устрою, регіональної економіки теж не знайшли відображення в нормативних документах, що регламентують реформування залізничного транспорту.

Зазначений підхід до регіональної економіки не сприяє ефективній взаємодії та співробітництву залізничного транспорту 3 органами місцевої влади. Одним 3 ключових завдань на сучасному етапі $\epsilon$ створення регіональної комплексності для реалізації економічних, соціальних, екологічних, науковотехнічних завдань.

Отже, метою статті $є$ розробка та обгрунтування теоретичних i практичних аспектів реструктуризації залізниць України на основі регіонально-галузевої моделі управління.

Виклад основного матеріалу дослідження. Регіональна комплексність - це не тільки агломерація і цілісність, це найвищий прояв взаємопов'язаного сполучення виробництва інфраструктури в межах регіону.

Економічний механізм регіонального утворення має забезпечити:

- додержання

екологічної

рівноваги, раціональне природокористування, виходячи з єдності, взаємозалежності всіх компонентів природного середовища, 3 урахуванням диверсифікації структури господарства регіону, ступеня розгалуженості, галузевого складу підприємств, характеру впливу застосовуваних технологій на навколишнє середовище;

- комплексне,

раціональне

використання природних ресурсів, економічно ефективне видобування всіх корисних компонентів із родовищ мінеральної сировини, використання та утилізацію всіх супутніх продуктів i відходів виробництва, усієї вторинної сировини, що утворюється на території регіону, незалежно від підпорядкованості і форм власності підприємств;

- раціональне використання всіх трудових ресурсів регіону з урахуванням їх статевовікової, соціальної, професійної та інших структур; регулювання економічними засобами міграційних процесів, забезпечуючи при цьому поєднання державних, регіональних та індивідуальних інтересів;

- економію витрат за рахунок створення і раціонального використання регіональної виробничої i соціальної інфраструктури, що обслуговує підприємства та організації всіх галузей національної економіки, усіх форм власності, нейтралізацію спроб створювати власні підприємства та елементи інфраструктури, що дублюють функції регіональної інфраструктурної бази, об'єднання 3 цією метою коштів на часткових засадах різних підприємств;

- раціональне використання товарно-матеріальних цінностей у межах району, у тому числі їх залишків, понаднормативних запасів, що 
утворюються на підприємствах і організаціях будь-якого підпорядкування, галузевої належності, форм власності;

\section{- ефективну реалізацію}

просування в економіку держави, практику науково-технічних ідей та закінчених розробок, що зароджуються в регіоні, передусім у рамках міждисциплінарних (як правило, найбільш продуктивних) досліджень, та передбачають міжгалузевий характер їх матеріалізації;

- ефективне

регіональних програм структури за участю організацій різних форм власності й підпорядкованості;

- повне, безпечне та якісне задоволення потреб регіону в перевезеннях пасажирів та вантажів.

Усі ці вимоги необхідно максимально враховувати при розробці матеріалів щодо реформування залізничного транспорту, і це, безумовно сприятиме ефективній співпраці з органами місцевого самоврядування.

Можна погодитись, що основний вплив на формування регіональних комплексів здійснюють економічні, соціально-демографічні та історико-етнічні фактори і умови, але було б помилково не враховувати транспортну складову цього впливу.

Практикою встановлено, що обсяги перевезень вантажів i пасажирів $\epsilon$ відображенням усієї діяльності держави, у першу чергу матеріального виробництва та соціальної сфери. Слід визначити, що економічні райони існують об'єктивно, незалежно від свідомості людей.

Функціонально-об'єктна система - це сукупність окремих властивостей об'єктів, що взаємодіють між собою через функціональні напрямки та принципи управління. Функціональними напрямками діяльності об'єктів є: управління перевезеннями, фінансово-економічні, тарифні, технічні, соціальні, ресурсні, інвестиційні, зовнішньоекономічні і т.п.

$$
\text { Принципами управління } є \text { : }
$$

спеціалізація, централізація, оперативність, горизонтальна взаємодія, регіональна компактність тощо.

Об'єктний підхід,

дозволяє розглядати суб'єкт господарської діяльності як сукупність системи яка пов'язана між собою об'єктами. Для кожного об'єкта розробляється відповідне дерево цілей.

За допомогою структури функціонально-об'єктної системи маємо можливість об'єднати функціональні напрямки i стратегії управління залізницями (рис. 1).

Принцип спеціалізації. Кожний структурний підрозділ, який входить до складу суб'єкта господарської діяльності залізниць, спеціалізується на відповідній роботі 3 утримання та обслуговування інфраструктури, організації руху поїздів i має вдосконалювати технологічний процес, застосовуючи передові методи та інновації.

Принцип централізації. Весь процес перевезень на території України здійснюється 3 одного центру Укрзалізниці, яка координує роботу за кожним галузевим напрямком.

Принцип оперативності. Bci установки, накази i розпорядження виконуються негайно зі зворотньою інформацією щодо їх виконання.

Принцип горизонтальної взаємодії. Під час виконання робіт з утримання та обслуговування інфраструктури та організації руху поїздів забезпечується чітка взаємодія, яку має контролювати апарат управління регіонального підприємства.

Принцип регіональної компактності. Розташування регіональних центрів управління перевезеннями і структурних підрозділів має забезпечити безаварійну роботу інфраструктури. Важливим завданням керівництва регіонального підприємства $\epsilon$ ефективна взаємодія 3 органами влади. Організаційна структура залізниць країни на основі функціональнооб'єктної системи управління представлена на рис. 2.

Вісник економіки транспорту і промисловості № 68, 2019 


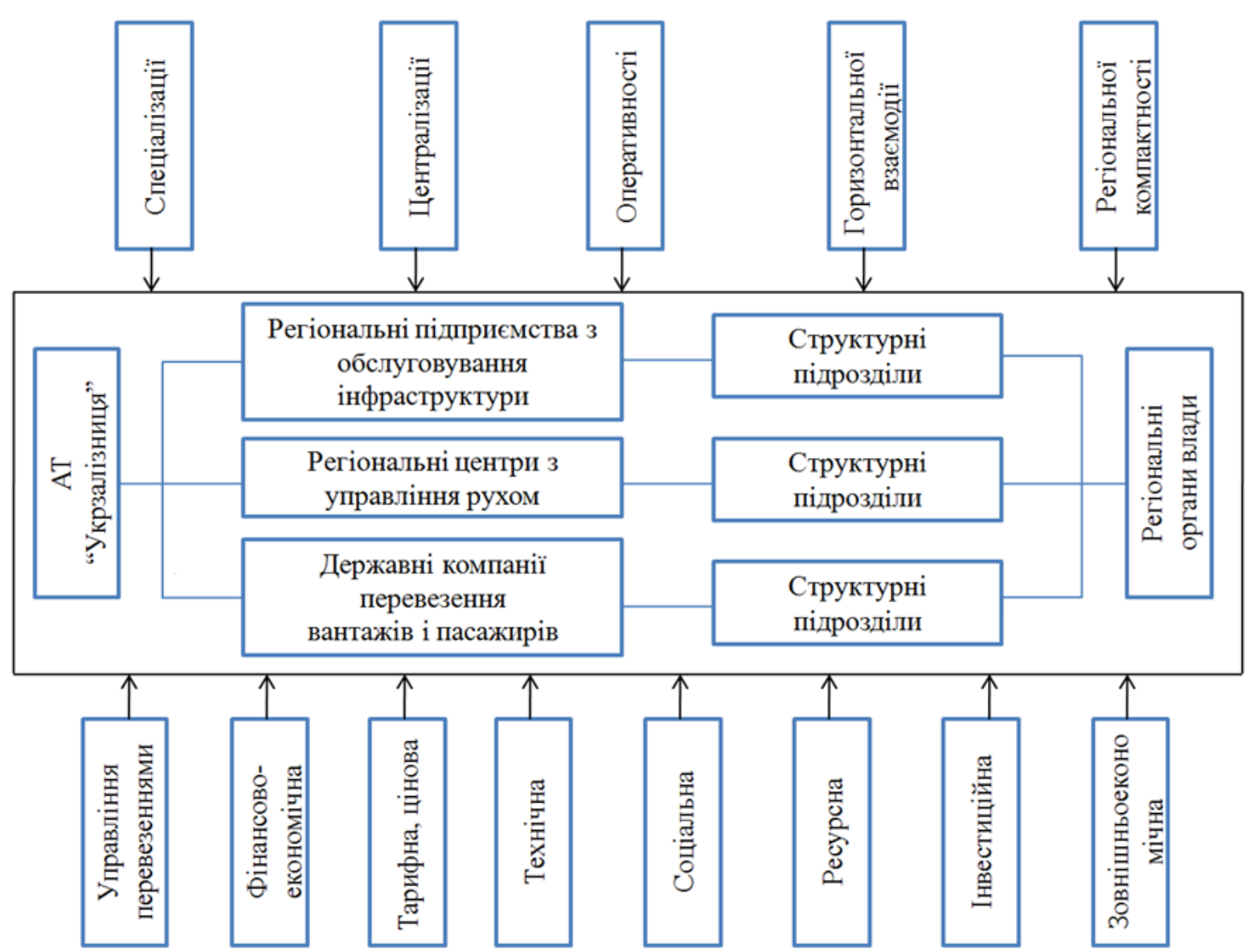

Рис. 1. Структура функціонально-об’єктної системи реформування залізниць Украӥни

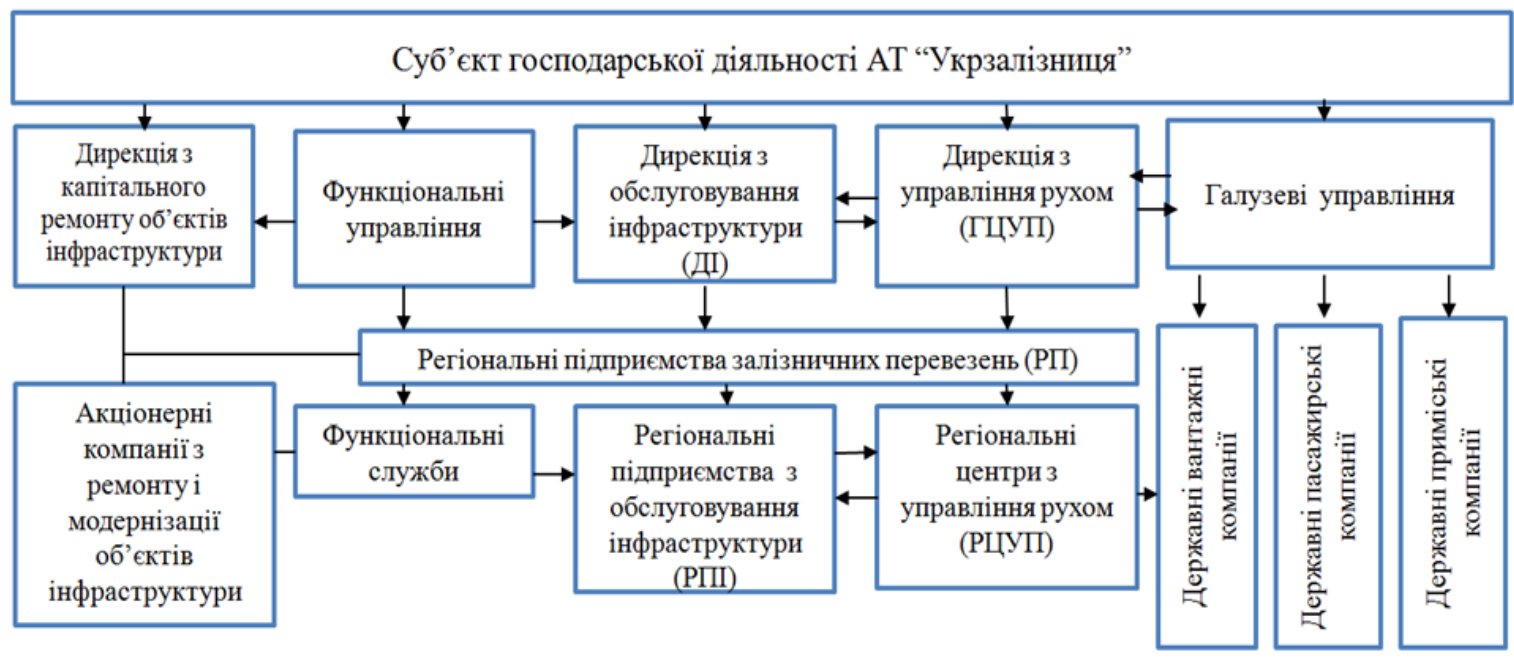

Рис. 2. Організаційна структура АТ «Укрзалізниия» на основі функиіонально-об'єктної системи управління

Основним стратегічним завданням регіонального підприємства залізничних перевезень $є$ забезпечення ефективності державної політики залізничного транспорту 3 повного задоволення в якісних перевезеннях пасажирів і вантажів та обслуговування інфраструктури згідно

Вісник економіки транспорту і промисловості № 68, 2019 
3 технічними вимогами, що регламентують безпеку руху поїздів. Формування адміністративнотериторіального устрою регіонального підприємства доцільно здійснювати в місцях i межах дислокації регіональних центрів управління перевезеннями.

Встановлено, що межі залізниць практично не змінювалися ще 3 пострадянських часів. Остання зміна адміністративного устрою було в 1979 році, коли 3 Одесько-Кишинівської залізниці виділилася Молдавська залізниця, а у 1991 році в час розпаду Радянського Союзу - Білгородський відділок Південної залізниці, який увійшов до складу Міністерства шляхів сполучення Російської федерації.

Слід зазначити, що існуючи області на теренах України сформувалися 3 урахуванням політичних та економічних чинників колишнього Радянського Союзу. А на сучасному етапі ні Уряд, ні Верховна рада цим важливим питанням не займається i, як показує час, займатися не будуть, що дуже шкода. Перш за все актуальність вирішення цієї проблеми постійно зростає насамперед у зв'язку 3 кардинальною зміною за минулі роки структури промислового виробництва i сільського господарства, які в свою чергу спричинили утворення нових районів тяжіння.

Доктором економічних наук, професором Жуком М.В. [12] (НАН України) були проведені дослідження, результати яких дають підставу стверджувати, що в Україні, мимо нашої волі, існують 10 економічних районів, а came:

- Донецький (Донецька, Луганська обл.);

- Карпатський (Закарпатська, Львівська, Івано-Франківська, Чернівецька);

- Кримський (Автономна Республіка Крим, м. Севастополь);

- Північно-Східний (Полтавська, Сумська, Харківська обл.);
- Північно-Західний

(Волинська, Рівненська обл.);

Подільський (Вінницька, Хмельницька, Тернопільська обл.);

Придніпровський

(Дніпропетровська, Запорізька обл.);

- Причорноморська (Миколаївська,

Одеська, Херсонська обл.);

Столичний (Житомирська,

Київська, Чернігівська обл., м.Київ);

- Центральний (Кіровоградська, Черкаська обл.).

Звичайно,

запропоноване розмежування районів не є безперечним, воно може бути розглянуто як один 3 варіантів. В межах даного адміністративного поділу пропонується на базі 6 існуючих залізниць і 23 дирекцій залізничних перевезень в місцях дислокацій регіональних центрів управління перевезень (РЦУП) утворити 10 регіональних підприємств. Створення РЦУП здійснювати на базі дирекцій залізничних перевезень i регіональних філій (3 урахуванням окупованих територій), а саме (рис. 3):

\section{- Донецький РЦУП-1}

Краснолиманської дирекції;

- Дніпровський РЦУП-2- на базі Дніпропетровської та Запорізької дирекцій;

- Харківський РЦУП-3 - на базі Харківської, Сумської та Куп'янської дирекцій;

- Полтавський РЦУП-4 - на базі Полтавської дирекцій;

- Київський РЦУП-5 - на базі Київської, Коростенської та Конотопської дирекцій;

- Вінницький РЦУП-6 - на базі Козятинської та Жмеринської дирекцій;

- Одеський РЦУП-7 - на базі

Одеської та Херсонської дирекцій;

- Шевченківський РЦУП-8 - на базі Знам'янської та Шевченківської дирекцій;

- Львівський РЦУП-9 - на базі

Львівської та Рівненської дирекцій;

- Карпатський РЦУП-10 - на базі

Івано-Франківської, Ужгородської та Тернопільської дирекцій.

Вісник економіки транспорту і промисловості № 68, 2019 


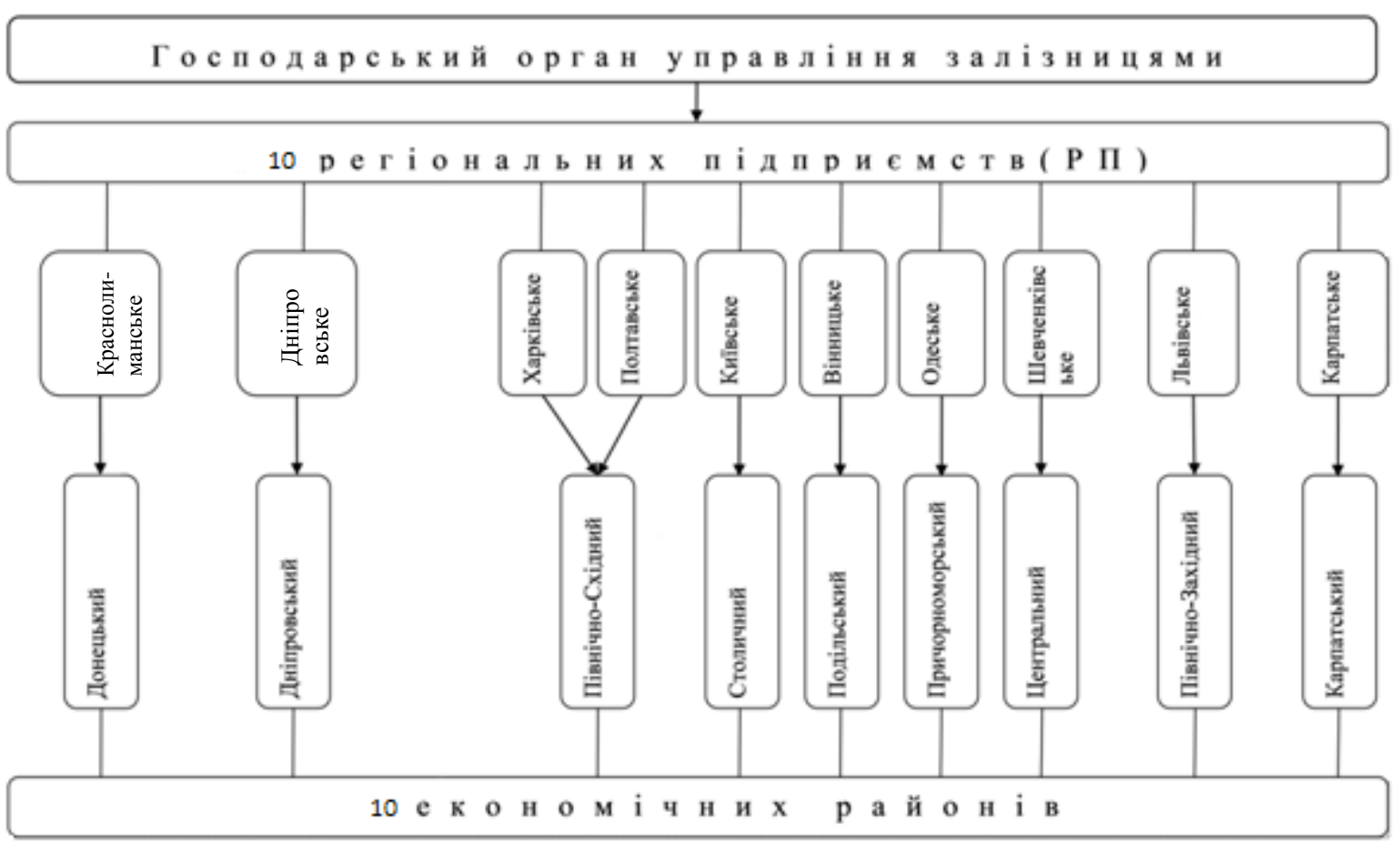

Рис. 3. Схеми дислокачії регіональних підприємств за економічними районами (з урахуванням окупованих територій)

Паралельно зі створенням центрів управління перевезеннями до 2020 року передбачити:

- поступовий вихід зі складу залізниць підрозділів, які відносяться до конкурентного сектору галузі;

- створення операторських компаній пасажирських перевезень, в тому числі їх вихід на ринок зі своїм власним парком локомотивів.

До складу регіональних підприємств пропонується включити регіональні підприємства 3 обслуговування інфраструктури (РПІ) і регіональні центри управління перевезеннями (РЦУП), які б підпорядковувалися по вертикалі суб'єкту господарювання «Українські залізниці».

Регіональні підприємства обслуговування інфраструктури управляють технологічним процесом через галузеві і функціональні служби: дистанціями колії, електропостачання, сигналізації та зв'язку, будівельномонтажних робот, інформаційнообчислювальними центрами, які здійснюють проведення регламентних робіт, планово-попереджувальні та аварійно-відновлювальні ремонти об'єктів інфраструктури.

Регіональні центри управління перевезеннями управляють технологічним процесом організації руху поїздів через диспетчерський апарат усіма залізничними станціями.

Висновок. Основними позитивними економіко-правовими результатами реалізації регіонально-галузевої моделі управління є:

1) гармонійне поєднання галузевої $\mathrm{i}$ регіональної форм управління;

2) ліквідація дублюючих функцій залізниць i їх дирекцій, створення регіональних підприємств на їх основі, що дозволить скоротити апарат управління на 2850 чол. і отримати річну економію фонду заробітної плати близько 300 млн. грн; результатами регіонального підприємства;

3) підвищення безпеки руху поїздів і якості обслуговування пасажирів за рахунок ефективного управління

Вісник економіки транспорту і промисловості № 68, 2019 
низовими ланками 3 обслуговування інфраструктури;

4) забезпечення правового статусу регіональної підприємства відповідно до Цивільного кодексу;

5) виконання Плану заходів 3 імплементації Угоди про асоціацію між Україною, 3 одного сторони, i Свропейським Союзом, європейськими Співдружністю 3 атомної енергії та їх державами, з іншого боку, затвердженого розпорядженням Кабінету Міністрів України від 17 вересня 2014 року № 847-р.

ПЕРЕЛІК ВИКОРИСТАНИХ ДЖЕРЕЛ

1. Постанова Кабінету Міністрів України «Про затвердження Державної цільової програми реформування залізничного транспорту на 2010-2015 роки» № 1390 від 16 грудня 2009 року [Електронний ресурс]. - Режим доступу: http://zakon.nau.ua/doc/?code=1390-09-

$\% \mathrm{EF}$.

2. Постанова Кабінету Міністрів України «Про затвердження Державної стратегії регіонального розвитку на період до 2020 року» №385 від 6 серпня 2014 року [Електронний ресурс]. - Режим доступу: http://search.ligazakon.ua/ 1_doc2.nsf /link1/KR 090891.html.

3. Гненний М.В. Оцінка збитків завданих пошкодженням вагонів / М.В. Гненний, О.М. Гненний // Вісн. Дніпропетр. нац. ун-ту залізн. трансп. ім. акад. В. Лазаряна. Д., 2012. - Вип. 40. - С. $262-266$.

4. Дейнека О.Г. Економічний механізм розрахунку витрат на вантажні перевезення залізниць: монографія / О.Г. Дейнека, А.Р. Божок. - Київ: ДЕТУТ, 2015. -172 c.

5. Дикань В.Л. Концепція інноваційного розвитку економіки України / В.Л. Дикань // Вісник економіки транспорту і промисловості. - Харків: УкрДУЗТ, 2015. - С. 9-20.

6. Кривопішин О.М. Регіональна політика залізниць України в період їх реформування / О.М. Кривопішин, Г.Д
Ейтутіс. // Залізничний транспорт України. - 2007. - №11. - C. 44-46.

7. Панченко О.I. Основні функції організаційно-економічної взаємодії залізничного транспорту з регіоном / O.I. Панченко // Вісник Харківського національного університету ім. В.Н. Каразіна. - Харків, 2001. - С. 140-141.

8. Ейтутіс Г.Д. Теоретико-практичні основи реформування залізниць України: Монографія / Г.Д. Ейтутіс / - Ніжин: ТОВ «Видавництво Аспект-Поліграф», 2009. $240 \mathrm{c}$.

9. Ейтутіс Г.Д. Методологічні підходи до проблем реформування залізничного транспорту на основі регіоналізації транспортного обслуговування / Г.Д. Ейтутіс // Економіст - 2009. - №12. - С. 33-39.

10. Ейтутіс Г.Д. Теоретикометодологічне обгрунтування місця залізничного транспорту, як суб'єкта природної монополії, у регіональній економіці / Г.Д. Ейтутіс // Залізничний транспорт України - 2010. - №1. - 67 с.

11. Yanovska V. Principles of the Feedback Action in Local Elements of Rail Interaction Yard / V. Yanovska, P. Yanjvsky, S. Lytvynenko, H. Nesterenko, L. Lytvynenko // International Journal of Engineering \& Technology. - 7(4.3). - 2018. - P. 196-200.

12. Жук М.В. Розміщення продуктивних сил і економіка регіонів України: підручник / М.В. Жук, В.П. Круль. Чернів. Нац. ун-т імені Юрія Федьковича. - Київ: Кондор, 2004. - 293 с.

\section{REFERENCES}

1. Cabinet of ministers of Ukraine. Postanova «Pro zatverdzhennya Derzhavnoyi cilovoyi programy reformuvannya zaliznychnogo transportu na 2010-2015 roky» № 1390 vid 16 grudnya 2009 roku [Elektronnyj resurs]. - Rezhym dostupu: http://zakon.nau.ua/doc/?code=1390-09$\% \mathrm{EF}$

2. Cabinet of ministers of Ukraine. Postanova «Pro zatverdzhennja Derzhavnoji strateghiji reghionaljnogho rozvytku na

Вісник економіки транспорту і промисловості № 68, 2019 
period do 2020 roku» №385 vid 6 serpnja 2014 roku [Elektronnyj resurs]. - Rezhym dostupu:

http://search.ligazakon.ua/l_doc2.nsf

/link1/KR 090891.html.

3. Gnennyj M.V. (2012) Ocinka zbytkiv zavdanyx poshkodzhennyam vagoniv [Estimation of damages caused by damage to wagons] / M.V. Gnennyj, O.M. Gnennyj // Visn. Dnipropetr. nacz. un-tu zalizn. transp. im. akad. V. Lazaryana. D. - Vol. 40. - pp. $262-266$.

4. Dejneka O.G. (2015) Ekonomichnyj mechanizm rozraxunku vytrat na vantazhni perevezennya zaliznycz: monografiya [Economic mechanism for calculating the costs of railways freight transportation] / O.G. Dejneka, A.R. Bozhok. - Kyyiv: DETUT. - 172 p.

5. Dykan V.L. (2015) Koncepciya innovacijnogo rozvytku ekonomiky Ukrayiny [Concept of innovative development of Ukraine's economy] / V.L. Dykan // Visnyk ekonomiky transportu i promyslovosti. Harkiv: UkrDUZT. - pp. 9-20.

6. Kryvopishyn O.M

(2007)

Regionalna polityka zaliznycz Ukrayiny $\mathrm{v}$ period ih reformuvannya [Regional policy of Ukraine's railways in the period of their reformation] / O.M. Kryvopishyn, G.D Ejtutis // Zaliznychnyj transport Ukrayiny. Vol. 11. - pp. 44-46.

7. Panchenko O.I. (2001) Osnovni funkciyi organizacijno-ekonomichnoyi vzayemodiyi zaliznychnogo transportu $\mathrm{z}$ regionom [Main functions of organizational and economic interaction of railway transport with the region] / O.I. Panchenko // Visnyk Xarkivskogo nacionalnogo universy`tetu im. V.N. Karazina. - Xarkiv. - pp. 140-141.
8. Ejtutis G.D. (2009) Teoretykopraktychni osnovy reformuvannya zaliznycz Ukrayiny: Monografiya [Theoretical and practical foundation of reforming Ukrainian railways] / G.D. Ejtutis / - Nizhyn: TOV «Vydavnycztvo Aspekt-Poligraf». - 240 p

$$
\text { 9. Ejtutis G.D. (2009) }
$$

Metodologichni pidhody do problem reformuvannya zalizny`chnogo transportu na osnovi regionalizaciyi transportnogo obslugovuvannya [Methodological approaches to the problems of reforming railway transport on the basis of regionalization of transport services] / G.D. Ejtutis // Ekonomist. - Vol. 12. - pp. 33-39.

10. Ejtutis G.D. (2010) Teoretykometodologichne obgruntuvannya miscya zaliznychnogo transportu, yak subyekta pryrodnoyi monopoliyi, u regionalnij ekonomici [Theoretical and methotological substantiation of the place of railway transport as a subject of natural monopoly in the regional economy]/ G.D. Ejtutis // Zaliznychnyj transport Ukrayiny. - Vol. 1 p. 67.

11. Yanovska V. (2018) Principles of the Feedback Action in Local Elements of Rail Interaction Yard / V. Yanovska, P. Yanjvsky, S. Lytvynenko, H. Nesterenko, L. Lytvynenko // International Journal of Engineering \& Technology. - 7(4.3). - pp. 196-200.

12. Zhuk M.V. Rozmishhennya produktyvnyh syl $i$ ekonomika regioniv Ukrayiny: pidruchnyk [Location of productive forces and economy of Ukraine's region] / M.V. Zhuk, V.P. Krul. Cherniv. Nacz. un-t imeni Yuriya Fedkovy`cha. Kyyiv: Kondor. -293 p. 